\title{
RESEARCHPAPER
}

\section{Influence of abiotic and biotic factors on the incidence of white fly, Bemisia tabaci (Gen.) on tomato}

\author{
S. K. MISHRA, R.K. SARAF AND VIKAS GUPTA \\ Dryland Horticulture Research and Training Centre (J. N. K. V. V. ), Garhakota, SAGAR (M.P.) INDIA \\ Email : mishradhrtc@gmail.com
}

Article Info : Received : 17.07.2017; Revised : 21.08.2017; Accepted : 19.09.2017

The incidence of whitefly was started in the fourth week of August (1.80/ plants). The whitefly population reached to its peak ( 21.10 white fly / plants) in the last week of September ( $39^{\text {th }}$ meteorological week). Average maximum $\left(33.61^{\circ} \mathrm{C}\right)$ and minimum $\left(18.58^{\circ} \mathrm{C}\right)$ temperature with average morning and evening relative humidity was 74.01 and 46.42 per cent, respectively, favoured the faster multiplication of white fly. The initial incidence of $C$. septempunctata was recorded in the last week of August and attained its peak in the last week of September. The population of C. septempunctata was influenced by the host insect as both were at peak the same time ( 3.50 beetles / 21.10 whitefly). Positive and non-significant correlation was found between whitefly and maximum temperature $(r=0.5546)$ and significant positive correlation was found between minimum temperature $(r=0,2025)$. The relationship between the whitefly population and rainfall was also negative and non-significant $(r=-0.1636)$. Positive nonsignificant correlation was found between beetle, $C$. septempunctata and maximum temperature $(r=0.2620)$, minimum temperature $(\mathrm{r}=0.2990)$.

Key words : Bemisia tabaci, Abiotic factors, C. septempunctata

How to cite this paper : Mishra, S.K., Saraf, R.K. and Gupta, Vikas (2017). Influence of abiotic and biotic factors on the incidence of white fly, Bemisia tabaci (Gen.) on tomato. Asian J. Bio. Sci., 12 (2) : 233-236.DOI : 10.15740/HAS/AJBS/12.2/233-236. 